\title{
Mycobacterium tuberculosis Infections in HIV-infected Patients
}

\section{HIV ile İnfekte Hastalarda Mycobacterium tuberculosis infeksiyonları}

\author{
Heval Can BiLEK'(iiD), Aydın DEVECi'(iiD), Esra TANYEL'(iiD)
}

${ }^{1}$ Department of Infectious Diseases and Clinical Microbiology, Ondokuz Mayıs University Faculty of Medicine, Samsun, Turkey

Cite this article as: Bilek HC, Deveci A, Tanyel E. Mycobacterium tuberculosis infections in HIV-infected patients. FLORA 2021;26(1):104-10.

\begin{abstract}
Introduction: Tuberculosis (TB) still continues to be the leading cause of death for Human Immunodeficiency Virus (HIV) infected patients, and it accounts for approximately one of three acquired immunodeficiency syndrome (AIDS) related deaths. The study aimed to analyze clinical and laboratory data of Mycobacterium tuberculosis infection in HIV infected patients.
\end{abstract}

Materials and Methods: Medical records of adult (aged $\geq 18$ years) HIV infected patients diagnosed and under medical care between January 2005 and November 2018 were obtained and analyzed retrospectively by searching hospital database system.

Results: Fifteen patients (4.5\%) had TB among the 336 HIV infected patients. There was no statistically significant difference between the age of HIV-infected patients with and without TB disease (38.07 \pm 8.48 vs $39.26 \pm 11.67 ; p$ : 0.697). Diagnosis of TB disease and HIV infection were concurrent during presentation in 9 (60\%) patients, while six (40\%) patients had a previous history of HIV infection and treatment. Five (83.3\%) of 6 patients receiving antiretroviral therapy (ART) had no viral suppression due to non-adherence. Median CD4 T lymphocyte count was $114 / \mathrm{mm}^{3}(0-436)$ at the time of TB diagnosis whereas it was $408 / \mathrm{mm}^{3}(1-1734)$ in those without TB disease at the time of initial HIV infection diagnosis, and the difference was statistically significant $(p<0.05)$. Odds ratio for CD4 T lymphocyte count less than 200 in HIV infected patients with TB disease was 14.89 (confidence interval 95\%: 4.08-54.34). While ten (66.7\%) patients had pulmonary involvement, five (33.3\%) patients had extrapulmonary involvement. There was no statistically significant difference between the median CD4 T lymphocyte counts of patients with pulmonary involvement $\left(107 / \mathrm{mm}^{3}, \mathrm{range:0-436)}\right.$ and extrapulmonary involvement $\left(140 / \mathrm{mm}^{3}\right.$, range: $\left.86-259\right)(p=0.391)$.

Conclusion: Tuberculosis disease should be considered in patients who have applied at advanced stages of HIV infection or whose virological suppression could not be achieved due to incompatibility with ART treatment.

Key Words: HIV; AIDS; Tuberculosis; CD4 


\title{
Öz
}

\section{HIV ile İnfekte Hastalarda Mycobacterium tuberculosis İnfeksiyonları}

\author{
Heval Can BiLEK', Aydın DEVECi', Esra TANYEL ${ }^{1}$
}

1 Ondokuz Mayıs Üniversitesi Tıp Fakültesi Hastanesi, İnfeksiyon Hastalıkları ve Klinik Mikrobiyoloji Anabilim Dalı, Samsun, Türkiye

Giriş: Tüberküloz (TB), insan immün yetmezlik virüsü (Human immunodeficiency virus: HIV) ile infekte hastalarda önde gelen ölüm nedeni olmaya devam etmekte olup, kazanılmış immün yetmezlik sendromu (Acquired immunodeficiency syndrome: AIDS) ile ilgili her üç ölümden yaklaşık birinin nedenini oluşturmaktadır. Bu çalışmada HIV ile infekte hastalarda gelişen TB hastalığının klinik ve laboratuvar verilerinin irdelenmesi amaçlandı.

Materyal ve Metod: Ocak 2005 ve Kasım 2018 tarihleri arasında HIV tanı ve tedavisi alan 18 yaş ve üzerindeki hastalar çalışmaya dahil edildi. Hastaların verileri hastane otomasyon kayıt sistemi taranarak retrospektif olarak elde edildi.

Bulgular: Çalışma döneminde 336 HIV ile infekte hasta tespit edildi. Hastaların 15 'inde (\%4.5) TB hastalığı saptandı. TB hastalığı olan ve olmayan HIV ile infekte hastaların yaş ortalaması (38.07 \pm 8.48 v $39.26 \pm 11.67$ ) arasında istatiksel olarak anlamlı bir fark yoktu (p:0.697). TB hastalığı tanısı, dokuz (\%60) hastada HIV infeksiyonu tanısı aldığı anda konulurken, altı (\%40) hastada ise daha önceden HIV infeksiyonu ve tedavisi öyküsü vardı. Antiretroviral tedavi (ART) deneyimli olan beş hastada tedavi uyumsuzluğu nedeniyle viral baskılanma sağlanmamıştı. TB hastalığı olan HIV ile infekte hastalarda TB tanısı sırasında ortanca CD4 T lenfosit sayısı 108/ $\mathrm{mm}^{3}$ (0-436); TB hastalığı olmayanlarda HIV infeksiyonunun tanısı sırasında ise 408/ $\mathrm{mm}^{3}$ (1-1734) olarak belirlendi ve aradaki fark istatistiksel açıdan anlamlıydı ( $p<0.05)$. TB hastalığı olan HIV ile infekte hastalarda CD4 T lenfosit sayısının 200/mm ${ }^{3}$ 'ün altında olma Odds oranı 14.89'du (\%95 güven aralığı: 4.08-54,34). Hastaların onunda (\%66.7) akciğer tutulumu mevcutken beş (\%33.3) hastada ise ekstrapulmoner tutulum mevcuttu. Akciğer tutulumu olan hastalar medyan CD4 T lenfosit sayısı 107/mm (0-436) iken ekstrapulmoner tutulumu olan hastalarda ise 140/ $\mathrm{mm}^{3}$ 'tü (86-259) ve her iki grup arasında istatiksel açıdan anlamlı bir fark yoktu $(p=0.391)$.

Sonuç: HIV infeksiyonunun ilerlemiş evrelerinde başvuran veya ART tedavisine uyumsuzluk nedeni ile virolojik baskılanma sağlanamamıs hastalarda tüberküloz hastalığı göz önünde bulundurulmalıdır.

Anahtar Kelimeler: HIV; AIDS; Tüberküloz; CD4

\section{INTRODUCTION}

Tuberculosis (TB) remains the leading cause of death in patients infected with the Human Immunodeficiency Virus (HIV). It accounts for about one of three deaths related to Acquired Immunodeficiency Syndrome (AIDS). It is estimated that approximately $9 \%$ of 10 million people who developed TB disease in 2017 are infected with $\mathrm{HIV}^{[1]}$. Both TB and HIV can neutralize the host's immune system responses through mechanisms that are not fully understood. HIV co-infection is the most substantial known risk factor for the progression of $\mathrm{TB}$ infection to active disease and increases the risk of latent $\mathrm{TB}$ reactivation by 20 times $^{[2,3]}$. Likewise, TB aggravates the clinical course of HIV infection and complicates antiretroviral therapy $(\mathrm{ART})^{[4,5]}$. We aimed to evaluate the prevalence of tuberculosis disease in HIV-infected patients, clinical types of disease, and immunological status of the patients.

\section{MATERIALS AND METHODS}

Medical records of adult (aged $\geq 18$ years) HIV-infected patients diagnosed and under medical care at Ondokuz Mayis University Research and Education Hospital between January 2005 and November 2018 were analyzed retrospectively by searching hospital database system. HIV infection was defined by the detection of HIV 1/2 antigen/ antibodies by the electrochemiluminescence immunoassay method (Cobas e411, Roche Diagnostics) and validation of samples in a public health laboratory by a descriptive method (Western blot, line immunoassay or indirect immunofluorescence). Viral load and CD4 $\mathrm{T}$ lymphocyte cell count of the patients were determined by real-time polymerase chain reaction (PCR) and peripheral blood analysis by flow cytometer method, respectively.

TB diagnosis was based on $M$. tuberculosis growth or positive molecular diagnostic tests (polymerase chain reaction; $\mathrm{PCR}$ ) in clinical samples 
or clinical (coughing for longer than three weeks, fatigue, fever) and radiological findings (cavitary lesions, pleural effusion, miliary pattern, hilar lymphadenopathy) consistent with TB. Mann Whitney $\mathrm{U}$ test and Student t-tests were used to analyze parametric data by using SPSS Statistics 21.0 software. Odds ratio was calculated for risk determination of CD4 T lymphocyte count. The study was approved by Ondokuz Mayis University Clinical Research Ethics Committee on 19.11.2019 with the decision number of $2019 / 720$.

\section{RESULTS}

It was determined that a total of 336 HIV-infected patients, including 52 (15.4\%) females and 284 (84.6\%) males, were diagnosed and under medical care during the study period. Anti-tuberculosis therapy was initiated in 15 (4.5\%) of these patients due to TB disease.

All patients diagnosed with TB disease were males. The mean age of HIV infected patients without TB disease was $39.26 \pm 11.67$ years whereas the mean age of patients with $\mathrm{TB}$ disease was $38.07 \pm 8.48$ years. There was no statistically significant difference between the two groups $(p=0.697)$.

Nine (60\%) patients were diagnosed with TB disease concurrent with initial HIV infection diagnosis and, six (40\%) patients were ART experienced patients due to earlier diagnosis of HIV infection. Virological suppression (HIV-RNA <50 copies/mL) was achieved in one (17\%) patient on ART whereas the remaining 5 (83\%) patients did not have viral suppression due to nonadherence to ART.

Median CD4 T lymphocyte count was 114/ $\mathrm{mm}^{3}$ (0-436) at the time of TB diagnosis, whereas it was $408 / \mathrm{mm}^{3}(1-1734)$ in those without
TB disease at the time of initial HIV infection diagnosis and the difference was statistically significant $(p<0.05)$ (Table 1$)$. Odds ratio for CD4 T lymphocyte count less than 200 in HIV infected patients with TB disease was 14.89 (confidence interval 95\%: 4.08-54.34).

It was determined that there was isolation of M. tuberculosis in nine (60\%) of fifteen patients; tuberculosis PCR positivity in six (50\%) of twelve patients; positive acid-fast bacilli (AFB) on direct microscopic examination in 8 (50\%) of fifteen patients (Table 2). Computerized tomography (CT) imaging revealed micronodules in nine (60\%) patients; mediastinal lymphadenopathy in nine (60\%) patients; cavitary nodules in five (33.3\%) patients; pleural effusion and pleural thickening in two (13.3\%) patients; conglomerate lymph nodes in two (13.3\%) patients; and meningeal involvement in $1(6.7 \%)$ patient. All patients had at least one abnormal finding in CT imaging.

While 10 (66.7\%) patients had pulmonary involvement, five (33.3\%) patients had extrapulmonary involvement including two (13.3\%) pleurisy, one $(6.7 \%)$ miliary, one (6.7\%) lymphadenitis and one (6.7\%) central nervous system involvement (Table 2). Median CD4 T lymphocyte counts of the patients with pulmonary involvement was $107 / \mathrm{mm}^{3}$ (0-436), whereas it was $140 / \mathrm{mm}^{3}$ (86-259) in patients with extrapulmonary involvement $(p=0.391)$.

Antituberculosis induction therapy including isoniazid, rifampicin, pyrazinamide and ethambutol were used for thirteen (86.7\%) patients for two months and followed by maintenance therapy including isoniazid and rifampicin for 10 months. Remaining two (13.3\%) patients were treated by rifabutin instead of rifampicin due to potential drug interaction with ART regime including a

Table 1. Characteristics and CD4 T lymphocyte median counts of HIV infected patients with and without TB disease

\begin{tabular}{lccc} 
& With TB Disease & Without TB disease & p \\
\hline Number of patients & & & \\
$\quad$ Female & $0(0)$ & $52(15.4 \%)$ & \\
$\quad$ Male & $15(4.5 \%)$ & $399(80.1 \%)$ & 0.697 \\
Age (years) & $38.1 \pm 8.5$ & $408 / \mathrm{mm}^{3}(1-1734)$ & $<0.05$ \\
CD4 T lymphocyte count (Median) & $114 / \mathrm{mm}^{3}(0-436)$ &
\end{tabular}


protease inhibitor. Dolutegravir dose was increased to $2 \times 50 \mathrm{mg}$ during antituberculosis treatment. $13(86.7 \%)$ patients recovered while two (13.3\%) patients died. Antituberculosis and ART regimes, adverse events, coinfections and outcome are summarized in Table 2.

\section{DISCUSSION}

It is estimated that one-third of the world population is latently infected with $M$. tuberculosis ${ }^{[6]}$. Approximately 10\% of individuals infected with $M$. tuberculosis develop clinical disease mainly resulting from reactivation or post-primary $\mathrm{TB}^{[7]}$. Therefore, while the risk of developing active $\mathrm{TB}$ in immunocompetent adults is 5-10\% throughout their lifetime, this risk increases annually between 5-15\% in HIV-infected individuals ${ }^{[8]}$. The prevalence of TB-HIV co-infection varies in different geographic regions; HIV prevalence in $\mathrm{TB}$ patients was reported to be $3.8-72.3 \%$, while $\mathrm{TB}$ prevalence in HIV-infected patients was reported as 2.9-64.5\%[9]. Global tuberculosis report of the World Health Organization (WHO) reported that HIV prevalence in newly diagnosed and recurrent tuberculosis cases was $0-4.9 \%$ in Turkey ${ }^{[10]}$. The prevalence of tuberculosis was found $4.5 \%$ among 1475 HIV-infected patients in an earlier study in Turkey ${ }^{[11]}$. Similarly, our study determined that the prevalence of tuberculosis in HIV-infected patients was 4.5\%.

In our study, the CD4 $\mathrm{T}$ lymphocyte median count of patients without tuberculosis disease was $408 / \mathrm{mm}^{3}$, whereas the CD4 T lymphocyte median count of patients with tuberculosis disease was less than $200 / \mathrm{mm}^{3}\left(114 / \mathrm{mm}^{3}\right)$ that is considered as severe immunosuppression. High Odds ratio for low CD4 T lymphocyte count $(<200 /$ $\mathrm{mm}^{3}$ ) in HIV infected patients with TB disease showed increased risk of TB disease among patients with low CD4 T lymphocyte count. One of the key features of AIDS is depletion of CD4 $\mathrm{T}$ lymphocytes that contributes significantly to the increased risk of reactivation of latent $\mathrm{TB}$ and predisposition to new tuberculosis infection. HIV has also been shown to disrupt apoptotic response of tumor necrosis factor (TNF) mediated macrophage and consequently facilitating bacterial survival ${ }^{[12]}$. Median CD4 T lymphocyte count of HIV-infected patients with TB disease was lower than patients without TB $(p<0.05)$.
Extrapulmonary tuberculosis (EPTB) is defined as TB disease that affects tissues and organs outside the pulmonary parenchyma, and the incidence of EPTB worldwide in 2016 was reported to be $15 \%[10]$. EPTB forms including pleural effusion, meningitis, lymphadenitis and pericardial disease are more common in HIV-infected patients, and it occurs in $70 \%$ of people with CD4 T lymphocyte count less than $100 / \mathrm{mm}^{3}$ and approximately $30 \%$ of people with CD4 T lymphocyte count above 300 cells $/ \mathrm{mm}^{3[13,14]}$. EPTB was determined in $33.3 \%$ of the patients with TB in our study.

The most common TB diagnostic method includes microscopic examination of the stained sputum for $\mathrm{AFB}^{[15]}$. Microscopy has the advantage of being cheap with acceptable specificity and relatively faster diagnostic test. However, clinical specimen must contain approximately ten mycobacteria per milliliter to be effective in staining ${ }^{[16]}$. The sensitivity of sputum microscopy in HIV infection ranges from $43-51 \%[17]$. Isolation of $M$. tuberculosis is much more sensitive than microscopy in the diagnosis of TB disease among HIV-infected patients ${ }^{[18]}$. Compared with microscopic evaluation, nucleic acid amplification tests (NAAT) have a better positive predictive value in both microscopic positive and negative samples ${ }^{[19,20]}$. In addition, NAAT provides faster results than the isolation of mycobacteria in culture that requires several weeks for isolation. Despite the obvious advantages of NAAT compared to conventional diagnostic tests, their use is limited in tuberculosis-endemic environments due to high cost and requirement of special equipment ${ }^{[21]}$. NAAT could only be studied from the clinical samples of twelve of sixteen HIV-infected tuberculosis patients, and 50\% were found to be positive. Although tuberculosis culturing yielded late results compared to NAAT, the fact that it is possible to work continuously in the laboratory, requires less technical opportunities, and the rate of isolation in our study was higher than NAAT, supports its diagnostic importance.

At advanced levels of immune suppression, $20 \%$ of HIV-infected patients with TB disease are estimated to have normal chest radiographs; however, CT assessment of such patients often shows subtle abnormalities, including small no- 


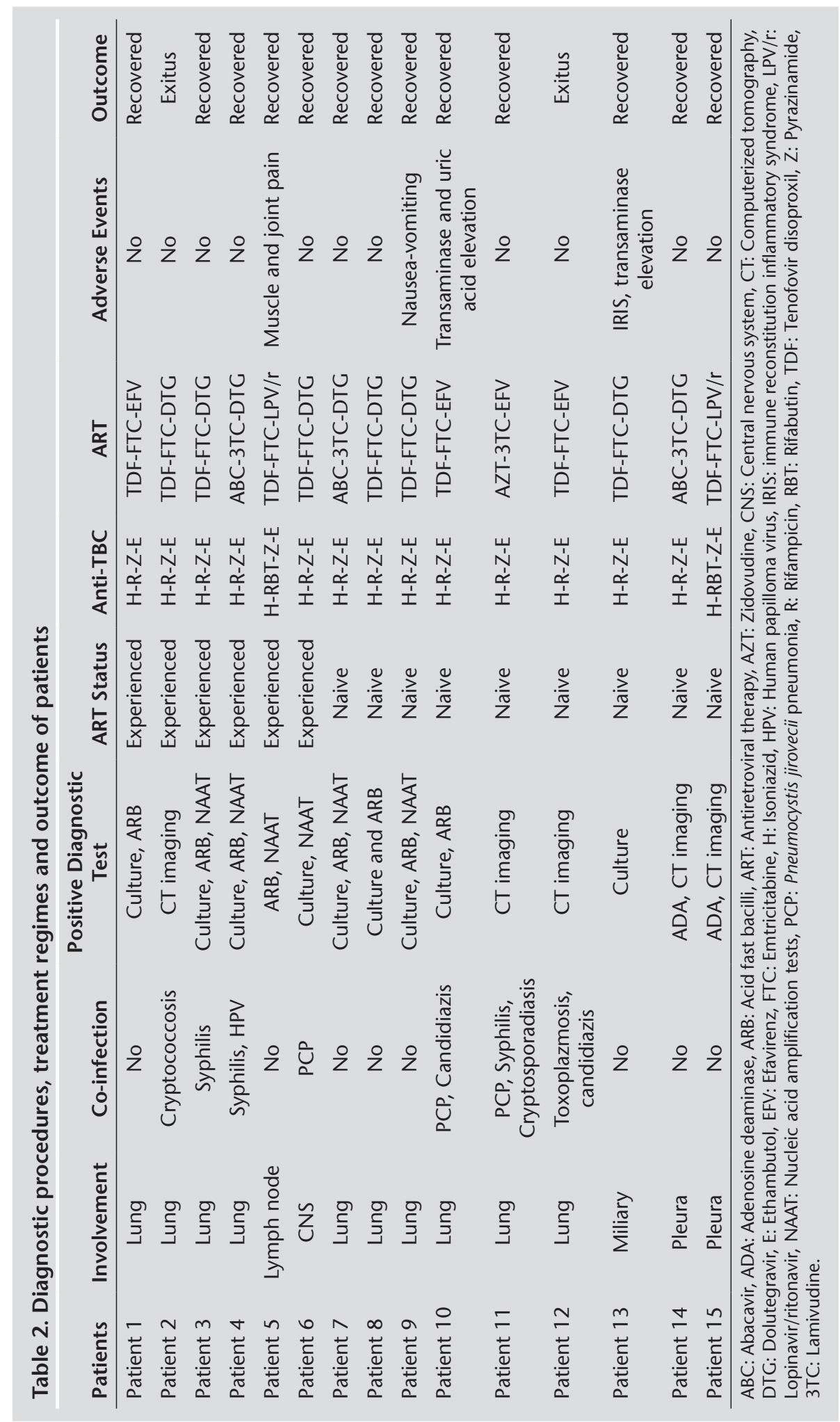


dules and lymph node enlargement ${ }^{[22,23]}$. After the diagnosis of EPTB, the relationship with pulmonary TB should always be investigated, as they can coexist. Although the treatment basis is the same, the contagious nature of pulmonary $\mathrm{TB}$ requires some additional tests that need to be done ${ }^{[24,25]}$. In our study, chest CT findings were found to be very supportive in terms of diagnosis, since the lung is the primary focus for $\mathrm{TB}$ infection or the source tissue for the spread of the infection to other tissues.

Our study has some limitations; first it is a retrospective study, and data collection is based on automated database, therefore there were lack of some information regarding socioeconomic status of patients, diagnostic procedures and adverse events. Gold standard diagnostic test was positive in nine of the fifteen patients and remaining six patients were diagnosed according to clinical, radiological and biochemical findings. Small sample size is another limitation of the study.

In our study, it was determined that low CD4 $\mathrm{T}$ lymphocyte count is the main factor in the emergence of TB disease. TB disease should not only be considered in patients admitted at advanced stages of HIV infection but also in patients who are non-adherent to the ART treatment. However, the diagnostic gold standard for active TB is isolation of bacteria by culture or molecular methods in HIV-infected people, patients with typical clinical signs may be diagnosed by using CT imaging in the absence of bacterial isolation.

\section{ETHICS COMMITTEE APPROVAL}

The ethical approval for this study was obtained fron Ondokuz May1s University Clinical Research Ethics Committee (Decision no: B.30.2.ODM.0.20.08/820-887, Date: 19.11.2019).

\section{CONFLICT of INTEREST}

The authors declare that they have no conflict of interest.

\section{AUTHORSHIP CONTRIBUTIONS}

Concept and Design: AD, HCB, ET

Analysis/Interpretation: $\mathrm{HCB}, \mathrm{AD}, \mathrm{ET}$

Data Acquisition: $\mathrm{HCB}, \mathrm{AD}, \mathrm{ET}$

Writing: HCB, AD, ET
Revision and Correction: HCB, AD, ET

Final Approval: $\mathrm{HCB}, \mathrm{AD}, \mathrm{ET}$

\section{REFERENCES}

1. UNAIDS. Global HIV \& AIDS statistics-2019 fact sheet. HIV/tuberculosis (TB). Available from: https://www.unaids.org/en/resources/fact-sheetfact-sheet. Accessed date: 02.11.2019.

2. Getahun H, Gunneberg C, Granich R, Nunn P. HIV infection-associated tuberculosis: the epidemiology and the response. Clin Infect Dis 2010;50(3):201-S207.

3. Selwyn PA, Hartel $D$, Lewis VA, Schoenbaum EE, Vermund $\mathrm{SH}$, Robert $\mathrm{S}$, et al. A prospective study of the risk of tuberculosis among intravenous drug users with human immunodeficiency virus infection. N Engl J Med 1989;320:54550.

4. Whalen $C$, Horsburgh $C R$, Hom D, Lahart $C$, Simberkoff $M$, Ellner J. Accelerated course of human immunodeficiency virus infection after tuberculosis. Am I Respir Crit Care Med 1995;151:129-35.

5. Modjarrad K, Vermund SH. Effect of treating co-infections on HIV-1 viral load: a systematic review. Lancet Infect Dis 2010;10:455-63.

6. Dye C, Scheele S, Dolin P, Pathania V, Raviglione MC. Consensus statement. Global burden of tuberculosis: estimated incidence, prevalence, and mortality by country. WHO Global Surveillance and Monitoring Project. JAMA 1999;282:677-86.

7. Lillebaek T, Dirksen A, Vynnycky E, Baess I, Thomsen VO, Andersen $A B$, et al. Stability of DNA patterns and evidence of Mycobacterium tuberculosis reactivation occurring decades after the initial infection. J Infect Dis 2003;188:1032-9.

8. Aaron L, Saadoun D, Calatroni I, Launay O, Memain N, Andersen $A B$. Tuberculosis in HIV-infected patients: a comprehensive review. Clin Microbiol Infect 2004; 10: 388-98.

9. Gao J, Zheng P, Fu H. Prevalence of TB/HIV co-infection in countries except China: a systematic review and meta-analysis. PLoS One 2013;8(5):e64915.

10. World Health Organization (WHO). Global tuberculosis report 2019. Available from: https://apps.who.int/iris/ bitstream/handle/10665/329368/9789241565714-eng. pdf?ua=1. Accessed date: 02.11.2019.

11. Gümüşer F, Altınkaynak $M$, Yıldız Sevgi $D$, Altuntaş Aydın $O ̈$, Mete $B$, Gündüz $A$, et al. Human immunodeficiency virus and tuberculosis coinfection: clinical features and predictors of mortality. Turk J Med Sci 2018;14;48(3):503-8.

12. Patel NR, Zhu J, Tachado SD, Zhang J, Wan Z, Saukkonen JJ, et al. HIV impairs TNF-alpha mediated macrophage apoptotic response to Mycobacterium tuberculosis. J Immunol 2007; 179:6973-80.

13. Jones BE, Young SM, Antoniskis D, Davidson PT, Kramer F, Barnes PF. Relationship of the manifestations of tuberculosis to CD4 cell counts in patients with human immunodeficiency virus infection. Am Rev Respir Dis 1993;148:1292-7. 
14. Naing C, Mak JW, Maung M, Wong SF, Kassim Al. Meta-analysis: the association between HIV infection and extrapulmonary tuberculosis. Lung 2013;191:27-34.

15. Hopewell P, Pai M, Maher D, Uplekar M, Raviglione MC. International standards for tuberculosis care. Lancet Infect Dis 2006;6:710-25.

16. Sonnenberg P, Glynn JR, Fielding K, Murray J, Godfrey-Faussett $P$, Shearer $S$. How soon after infection with HIV does the risk of tuberculosis start to increase? A retrospective cohort study in South African gold miners. I Infect Dis 2007;191:150-8.

17. Cattamanchi A, Dowdy DW, Davis JL, Worodria W, Yoo S, Joloba $M$, et al. Sensitivity of direct versus concentrated sputum smear microscopy in HIV-infected patients suspected of having pulmonary tuberculosis. BMC Infect Dis 2009;9:53.

18. World Health Organization (WHO). Improving the diagnosis and treatment of smear-negative pulmonary and extrapulmonary tuberculosis among adults and adolescents: recommendations for HIV-prevalent and resource-constrained settings. Available from: https://apps.who.int/iris/bitstream/handle/10665/69463/WHO_HTM_TB_2007.379_ eng.pdf; jessionid $=E C A 6 C D 5 A 1 A 3 D 06 B 99871287 F 80 E-$ $B 0 A D 9$ ? sequence $=1$. Accessed date: 02.11.2019.

19. Centers for Disease Control and Prevention. Updated guidelines for the use of nucleic acid amplification tests in the diagnosis of tuberculosis. MMWR Morb Mortal Wkly Rep 2009;58:7-10.

20. Kambashi B, Mbulo G, McNerney R, Tembwe R, Kambashi $A$, Tihon $V$, et al. Utility of nucleic acid amplification techniques for the diagnosis of pulmonary tuberculosis in Sub-Saharan Africa. Int J Tuberc Lung Dis 2001;5:364-9.
21. Piersimoni C, Scarparo C. Relevance of commercial amplification methods for direct detection of Mycobacterium tuberculosis complex in clinical samples. J Clin Microbiol 2003;41:5355-65.

22. Greenberg SD, Frager D, Suster B, Walker S, Stavropoulos C, Rothpearl A. Active pulmonary tuberculosis in patients with AIDS: spectrum of radiographic findings (including a normal appearance). Radiology 1994;193:115-9.

23. Leung AN. Pulmonary tuberculosis: the essentials. Radiology 1999;210:307-22.

24. Centers for Diseases Control and Prevention. Guidelines for the investigation of contacts of persons with infectious tuberculosis; recommendations from the national Tuberculosis Controllers Association and CDC, and Guidelines for using QuantiFERON®-TB Gold test for detecting Mycobacterium tuberculosis infection. United States. MMWR 2005;54:1-55.

25. Orenstein EW, Basu S, Shah NS, Andrews JR, Friedland GH, Moll AP, et al. Treatment outcomes among patients with multidrug-resistant tuberculosis: systematic review and meta-analysis. Lancet Infect Dis 2009;9:153-61.

\section{Address for Correspondence/Yazıșma Adresi}

\section{Doc. Dr. Aydın DEVECI}

Ondokuz Mayıs Üniversitesi Tip Fakültesi Hastanesi, İnfeksiyon Hastalıkları ve Klinik Mikrobiyoloji Kliniŏi, Samsun-Türkiye

E-mail: adeveci@omu.edu.tr 